International Research Journal of Management, IT \& Social Sciences
Available online at https://sloap.org/journals/index.php/irjmis/
Vol. 7 No. 1, January 2020, pages: 128-137
ISSN: 2395-7492
https://doi.org/10.21744/irjmis.v7n1.830

\title{
The Effect of Ownership Structure on Financial Distress with Audit Committee as Moderating Variable
}

I Kadek Widhiadnyana ${ }^{a}$ Dewa Gede Wirama ${ }^{\text {b }}$

\section{Article history:}

Submitted: 27 November 2019

Revised: 18 December 2019

Accepted: 04 January 2020

\section{Keywords:}

audit committee;

financial distress;

institutional ownership;

managerial ownership;

ownership structure;

\begin{abstract}
The purpose of this study is to obtain empirical evidence about the effects of managerial ownership and institutional ownership on financial distress and examine the role of the audit committee in moderating the effect of managerial ownership and institutional ownership on financial distress. The sampling technique used is the nonprobability sampling method with a purposive sampling technique. The data used in this study are secondary data obtained from the financial statements of manufacturing companies listed on the Indonesia Stock Exchange in the 2014-2018 period. Data are analyzed using ordinal logistic regression. The results of the analysis show that managerial ownership has no effect on financial distress, institutional ownership has a negative effect on financial distress, and the audit committee does not moderate the relationship between either managerial ownership or institutional ownership on financial distress.
\end{abstract}

International research journal of management, IT and social sciences (C) 2020. This is an open access article under the CC BY-NC-ND license (https://creativecommons.org/licenses/by-nc-nd/4.0/).

Corresponding author:

I Kadek Widhiadnyana,

Faculty of Economics and Business, Udayana University, Denpasar, Indonesia.

Email address: widhiadnyana527@gmail.com

${ }^{a}$ Udayana University, Denpasar, Indonesia

${ }^{\text {b }}$ Udayana University, Denpasar, Indonesia 


\section{Introduction}

Financial distress is the stage of decline in financial conditions experienced by a company before bankruptcy (Platt \& Platt, 2002). Financial distress caused by the company due to cash flow difficulties, the amount of debt, and losses due to operations (Harmawan, 2013). During the period 2014-2018, there were 24 manufacturing companies that published financial statements on the Indonesia Stock Exchange (IDX) which suffered losses for 3 consecutive years. Of these 24 companies, 6 of them experienced an increase in debt from 2014-2018 and 10 companies had a negative operating cash flow value for 3 years.

Poor implementation of corporate governance principles is one of the causes of the collapse of big companies in the world (Sutojo \& Aldridge, 2008). Corporate governance is a system used to direct and control the company's business activities (Sutojo \& Aldridge, 2008). The ownership structure is one of the internal factors of a company that influences the application of corporate governance principles (Sutojo \& Aldridge, 2008). The ownership structure in a company will play an important role in determining the success or failure of a company (Udin et al., 2017). The ownership structure used in this study is managerial ownership and institutional ownership. Managerial ownership is ownership of shares by company managers including ownership by the board of directors and commissioners. While institutional ownership is the percentage of shares owned by institutional investors, such as insurance companies, investment companies, and banks (Moradi et al., 2012). The greater managerial ownership and institutional ownership in a company will have an impact on the more efficient use of company assets so that the potential for financial distress can be minimized.

Agency theory is the basis for the implementation of corporate governance as a mechanism of supervision and control (Harahap, 2017). The audit committee is a corporate governance mechanism used to control and oversee company management (Rahmawati, 2016; Putri \& Sujana, 2018). The audit committee functions to carry out internal control related to accounting policies, risk management, compliance with applicable legal provisions, and compliance with the company's articles of association and bylaws, as well as the process of disclosure of the company's financial statements (Sutojo \& Aldridge, 2008). The number of members of the audit committee has a close relationship with how much resources are allocated to deal with the problems facing the company. Increasing the number of audit committees in a company will facilitate the audit committee in exchanging ideas to solve problems faced by the company so that the company can avoid conditions of financial distress.

Several factors that have been investigated by previous studies in explaining the phenomenon of financial distress are managerial ownership (Affiah \& Muslih, 2018; Luqman et al., 2018; Zahra et al., 2018) institutional ownership (Filsaraei \& Moghaddam (2016); Chrissentia \& Syarief, 2018; Septiani \& Dana, 2019), proportion of independent commissioners (Yudha \& Fuad, 2014; Fathonah, 2016; Pramudena, 2017), number board of directors (Hanafi \& Breliastiti, 2016; Baklouti et al., 2016; Harahap, 2017), profitability (Carolina et al., 2017; Kalimah, 2017; Masdupi et al., 2018), liquidity (Khaliq et al., 2014; Sari \& Putri, 2016; Waqas \& Md-Rus, 2018), leverage (Ufo, 2015; Ong'era et al., 2017; Agustini \& Wirawati, 2019), operating capacity (Yayanti \& Yanti, 2016; Rahmawati, 2016; Ratna \& Marwati, 2018), and company size (Putri \& Merkusiwati, 2014; Filsaraei \& Moghaddam (2016); Rahmawati \& Handriyana, 2018; Dewi \& Ramantha, 2019). The profitability, liquidity, leverage, and operating capacity variables cannot be used in this study because the Altman model used to measure financial distress already includes these ratios. The variable proportion of the independent board of commissioners in most studies showed a negative effect on financial distress. The company size variable in most studies showed has no effect on financial distress. Managerial ownership and institutional ownership variables in several studies still show inconsistent results. The inconsistency of the results of the study caused the researcher to conduct further research by adding audit committee variables as moderating variables. The reason the researcher uses the audit committee variable is that this research focuses on agency theory that explains the associated conflict of interest between managers and shareholders. This conflict of interest causes shareholders to be willing to pay a monitoring fee to ensure that managers act in the interests of shareholders. An audit committee is a form of supervision costs incurred by shareholders.

\section{Literature review and hypothesis development Agency theory}

Jensen \& Meckling (1976), describe agency relationships as contracts where one or more people (principals) involve another person (agent) to perform some services on behalf of the principal which involves the delegation of some decision making authority to the agent. Eisenhardt (1989), states that there are three assumptions of human nature, namely humans have selfishness, humans have limited thinking power about future perceptions, and humans always

Widhiadnyana, I. K., \& Wirama, D. G. (2020). The effect of ownership structure on financial distress with audit committee as moderating variable. International Research Journal of Management, IT and Social Sciences, 7(1), 128-137. https://doi.org/10.21744/irjmis.v7n1.830) 
avoid risk. Selfish human nature will lead to the emergence of opportunistic behavior from every parties in the company. Managers will utilize the information asymmetry they have to be able to create maximum profits for themselves. Information asymmetry occurs when managers as internal parties have more information than shareholders as external parties (Fadhilah \& Syafruddin, 2013). The existence of information asymmetry causes shareholders to be willing to pay a monitoring fee called the agency cost (Yudiana \& Yadnyana, 2016). One way to minimize agency costs incurred by a company is by increasing share ownership by managers (Jensen \& Meckling, 1976) and institutions (Bodroastuti, 2009).

\section{Stewardship theory}

Stewardship theory emphasizes organizational management in creating harmony between shareholders and managers in achieving common goals (Anton, 2010). Managers as stewards will try to work together when there are differences in interests between principal and stewards. The manager will act in accordance with the interests of shareholders for the realization of company goals (Raharjo, 2007). Stewardship theory in this study is used to explain the effect of managerial ownership on financial distress. Share ownership by management will create a sense of ownership within the manager so that the manager's orientation does not only focus on the bonus that will be received at this time, but will be more focused on improving the company's long-term performance in order to achieve the planned objectives.

\section{Alignment effect theory}

Fan \& Wong (2002), define the effect of alignment as the actions of controlling shareholders that are aligned with the interests of non-controlling shareholders. Greater cash flow rights are a commitment to controlling shareholders to limit expropriation (Porta et al., 1999). Ownership of cash flow by the controlling shareholder can reduce his desire to expropriate and increase his desire to pay cash dividends (Sanjaya, 2010). The alignment effect theory in this study is used to explain the effect of institutional ownership on financial distress. Institutions as parties who invest shares in companies certainly hope to get dividends from their investments.

\section{Effect of managerial ownership on financial distress}

Agency conflict that occurs in a company is caused because shareholders and managers have a conflict of interests to maximize their respective utility. Managerial ownership is a way that can be used to unify the choices of managers with the interests of shareholders. Managerial ownership will create a sense of ownership in managers. Managerial ownership will cause managers to be more oriented towards the long-term performance of the company than the bonus that will be received at this time. Increasing the percentage of managerial ownership will be able to minimize the potential for financial distress experienced by the company. Research conducted by Pramudena (2017); Affiah \& Muslih (2018); Luqman et al. (2018); and Zahra et al. (2018), states that managerial ownership has a negative effect on financial distress. Based on these reasons, the hypothesis that can be developed in this study is.

$\mathrm{H}_{1}$ : Managerial ownership has a negative effect on financial distress.

\section{Effect of institutional ownership on financial distress}

Agency theory is the basis for the implementation of corporate governance as a mechanism of supervision and control (Harahap, 2017). Institutional ownership is one form of oversight and control mechanism for managers' opportunistic behavior. A large proportion of institutional ownership can help the monitoring process so it can effectively control the manager's performance. The greater institutional ownership will have an impact on the more efficient use of company assets so that the potential for financial distress can be minimized. Research conducted by Filsaraei \& Moghaddam (2016); Chrissentia \& Syarief (2018); Luqman et al. (2018); and Septiani \& Dana (2019), states that the institutional ownership has a negative effect on financial distress. Based on these reasons, the hypothesis that can be developed in this study is.

$\mathrm{H}_{2}$ : Institutional ownership has a negative effect on financial distress. 
The Role of the Audit Committee in Moderating the Effect of Managerial Ownership on Financial Distress

Managerial ownership will cause managers to tend to engage in value creation activities that can increase the company's long-term competitive advantage (Saleh et al., 2009). Stewardship theory states that managers as stewards will behave according to common interests in an effort to achieve organizational goals. However, the task of achieving the goals of the organization is not only the responsibility of the manager but also all elements of the company. Managers as those who carry out the planning and decision making will certainly need help from other parties to control and supervise the activities of the company. The audit committee is a corporate governance mechanism that has functions to carry out internal control related to company activities. Based on these reasons, the hypothesis that can be developed in this study is.

$\mathrm{H}_{3}$ : The audit committee reinforces the negative effect of managerial ownership on financial distress.

\section{The Role of the Audit Committee in Moderating the Effects of Institutional Ownership on Financial Distress}

Corporate governance is a mechanism used to balance the actions and choices of managers with the interests of shareholders (Susanti, 2011). Institutional ownership is one part of the corporate governance mechanism. The percentage of share ownership by an institution in a company tends to be large, thereby causing the institution to have the right to participate in overseeing and controlling the activities of the company. However, institutional ownership is ownership of shares by outsiders. The position of institutions outside the company causes them to not be able to know the problems facing the company in detail and on time. The audit committee is another corporate governance mechanism within a company that is responsible for overseeing financial reporting, risk management, and control, as well as corporate governance of a company (Komite Nasional Kebijakan Governance, 2002). Based on these reasons, the hypothesis that can be developed in this study is.

$\mathrm{H}_{4}$ : The audit committee reinforces the negative effect of institutional ownership on financial distress.

\section{Materials and Methods}

This research was conducted on manufacturing companies listed on the Indonesia Stock Exchange (IDX) in 20142018, with a total of 746 companies. The sample in this study was determined using a purposive sampling technique. The sample criteria that will be used in this study are (1) manufacturing companies that publish annual financial reports in 2014-2018 and (2) manufacturing companies that have managerial ownership and institutional ownership in 20142018. Based on these criteria, the number of samples used in this study was 358 companies.

Financial distress is measured using the model Altman (2013), with the equation formula is:

$\mathrm{Z}$-score $=1.2 \mathrm{X}_{1}+1.4 \mathrm{X}_{2}+3.3 \mathrm{X}_{3}+0.6 \mathrm{X}_{4}+0.99 \mathrm{X}_{5}$

Information:

$\mathrm{X}_{1}=$ working capital / total assets

$\mathrm{X}_{2}=$ retained earnings / total assets

$\mathrm{X}_{3}=$ earnings before interest and tax / total assets

$\mathrm{X}_{4}=$ market value of equity / book value of debt

$\mathrm{X}_{5}=$ sales / total assets

The scales used in classification are as follows:

Z-score $<1.81 \quad=$ financial distress

$1.81 \leq Z$-score $\leq 2.99 \quad=$ zone of ignorance or gray area

Z-score $>2.99 \quad=$ non-financial distress

Managerial ownership is measured by total shares owned by management divide total shares outstanding. Institutional ownership is measured by total shares owned by the institution divide total shares outstanding. The audit committee in this study was measured using total members of the audit committee owned by the company.

The data analysis technique used in this study is the ordinal logistic regression analysis. The use of ordinal logistic regression because the dependent variable has more than two categories and consists of an ordinal scale (ranking).

Widhiadnyana, I. K., \& Wirama, D. G. (2020). The effect of ownership structure on financial distress with audit committee as moderating variable. International Research Journal of Management, IT and Social Sciences, 7(1), 128-137. https://doi.org/10.21744/irjmis.v7n1.830) 
Companies that fall into the financial distress category are given symbol 3, gray area is given symbol 2 , and nonfinancial distress is given symbol 1 .

\section{Results and Discussions}

The sample used in this study were 358 manufacturing companies listed on the Indonesia Stock Exchange in 20142018. Of these, 120 companies were found in financial distress, 65 companies in the gray area, and 173 companies in non-financial distress.

\section{Descriptive Statistics}

Descriptive statistics provide information about the characteristics of the research variables consisting of the number of observations, minimum values, maximum values, mean values, and standard deviations. Table 1 shows the results of the descriptive statistics.

Table 1

Descriptive statistics

\begin{tabular}{llllll}
\hline Variable & Samples & Minimum & Maximum & Mean & $\begin{array}{l}\text { Standard } \\
\text { Deviation }\end{array}$ \\
\hline Financial Distress & 358 & 1.00000 & 3.00000 & 1.85000 & 0.94000 \\
Managerial Ownership & 358 & 0.00001 & 0.79280 & 0.07762 & 0.13298 \\
Institutional Ownership & 358 & 0.00900 & 0.98950 & 0.65117 & 0.20336 \\
Audit Committee & 358 & 2.00000 & 6.00000 & 3.09000 & 0.42600 \\
\hline
\end{tabular}

Table 1 shows the mean value of financial difficulties is 1.85000 . This value indicates that in general, the company under study is in a non-financial distress condition. The mean value of managerial ownership of 0.07762 means that the average total shares owned by the board of commissioners and directors in a company are 7.762 percent of the total shares outstanding. The mean value of institutional ownership of 0.65117 means that the average total shares owned by institutional investors such as insurance companies, investment companies, and banks in a company are 65.117 percent of the total shares outstanding. The mean value of the audit committee of 3.09000 means that the average number of audit committees is 3 members.

\section{Hypothesis testing}

Table 2 shows the results of ordinal logistic regression testing with a significance of $5 \%$.

Table 2

Regression logistic ordinal test result

\begin{tabular}{llll}
\hline Information & & -2 Log Likelihood & Significance \\
\hline $\begin{array}{l}\text { Model Fitting } \\
\text { Information }\end{array} \quad$ Intercept only & 722.807 & - \\
& Final & 710.723 & 0.034 \\
Information & & \\
Constant & FD $=1$ & -3.253 & Significance \\
& FD = & -2.480 & 0.030 \\
Managerial Ownership $\left(\mathrm{X}_{1}\right)$ & 11.705 & 0.097 \\
Institutional Ownership $\left(\mathrm{X}_{2}\right)$ & -2.419 & 0.240 \\
Audit Committee $\left(\mathrm{X}_{3}\right)$ & -1.095 & 0.024 \\
Managerial Ownership*Audit Committee $\left(\mathrm{X}_{1} \mathrm{X}_{3}\right)$ & -11.045 & 0.299 \\
Institutional Ownership*Audit Committee $\left(\mathrm{X}_{2} \mathrm{X}_{3}\right)$ & 0.441 & 0.219 \\
Test of Parallel Lines & & 0.147 \\
Nagelkerke R-Square & & 0.276 \\
\hline
\end{tabular}


The fitting information model shows a decrease of -2 log likelihoods from 722.807 to 710.723 and this decrease is significant at 0.034 . This shows that the model made is fit. The results of the test of parallel lines show a significance value of 0.276 . This shows that the model created is suitable. The coefficient of determination (Nagelkerke R-Square) of 0.038 means that the variation of financial distress that can be explained by variations in managerial ownership, institutional ownership, audit committee, interaction between managerial ownership and audit committee, and interaction between institutional ownership and audit committee is 3.8 percent, while the other 96.2 percent is influenced by other factors outside the research model.

Based on Table 2, two regression equations can be formed as follows:

Logit $\left(\mathrm{p}_{1}\right) \quad=-3.253+11.705 \mathrm{X}_{1}-2.419 \mathrm{X}_{2}-1.095 \mathrm{X}_{3}-11.045 \mathrm{X}_{1} \mathrm{X}_{3}+0.441 \mathrm{X}_{2} \mathrm{X}_{3}$

$\operatorname{Logit}\left(\mathrm{p}_{1}+\mathrm{p}_{2}\right)$

$=-2.480+11.705 \mathrm{X}_{1}-2.419 \mathrm{X}_{2}-1.095 \mathrm{X}_{3}-11.045 \mathrm{X}_{1} \mathrm{X}_{3}+0.441 \mathrm{X}_{2} \mathrm{X}_{3}$

Table 2 shows that managerial ownership, the interaction between managerial ownership and audit committee, and interaction between institutional ownership and audit committee have a significance value greater than 0.05 . Therefore, it can be concluded that managerial ownership has no effect on financial distress, the audit committee does not moderate the effect of managerial ownership on financial distress, and the audit committee does not moderate the effect of institutional ownership on financial distress. Institutional ownership has a significance value of less than 0.05 with a negative coefficient beta value. This shows that institutional ownership has a negative effect on financial distress.

\subsection{Effect of managerial ownership on financial distress}

The result of the analysis shows that managerial ownership has no effect on financial distress. The results of this study reject hypothesis $1\left(\mathrm{H}_{1}\right)$ which states managerial ownership has a negative effect on financial distress. The results of this study do not support the results of research conducted by Pramudena (2017); Affiah \& Muslih (2018); Luqman $e t$ al. (2018); and Zahra et al. (2018), which states that managerial ownership has a negative effect on financial distress. However, the results of this study support research conducted by Cinantya \& Merkusiwati (2015); Fathonah (2016); and Harahap (2017), which state that managerial ownership has no effect on financial distress. Managerial ownership has no effect on financial distress probably because the percentage of share ownership by management in the company is relatively small. The results of the descriptive statistical analysis show that the average number of shares owned by management is 7.762 percent of the total shares outstanding. Another factor that might also cause managerial ownership has no effect on financial distress is the unequal proportion of share ownership by management in the company. The percentage of the board of directors and commissioners who own shares is only 28.552 percent of the total management of the company.

\subsection{Effect of institutional ownership on financial distress}

The result of the analysis shows that institutional ownership has a negative effect on financial distress. The results of this study support hypothesis $2\left(\mathrm{H}_{2}\right)$ which states that institutional ownership has a negative effect on financial distress. Increasing the percentage of share ownership by institutional investors such as insurance companies, investment companies, and banks in a company will cause the financial distress experienced by companies to decline. The results of this study reinforce the results of research conducted by Filsaraei \& Moghaddam (2016); Chrissentia \& Syarief (2018); Luqman et al. (2018); and Septiani \& Dana (2019), which state that institutional ownership has a negative effect on financial distress.

\subsection{The role of the audit committee in moderating the effect of managerial ownership on financial distress}

The result of the analysis shows that the audit committee does not moderate the effect of managerial ownership on financial distress. Therefore, hypothesis $3\left(\mathrm{H}_{3}\right)$ which states that the audit committee reinforces the negative effect of managerial ownership on financial distress is rejected. A small proportion of share ownership by management results in company management not having sufficiently strong voting rights to make decisions relating to the company. The small voting rights cause the management of the company before making important decisions that need to get the approval of the controlling shareholder. This will cause the company's management to not be able to quickly respond to the findings and recommendations submitted by the audit committee.

Widhiadnyana, I. K., \& Wirama, D. G. (2020). The effect of ownership structure on financial distress with audit committee as moderating variable. International Research Journal of Management, IT and Social Sciences, 7(1), 128-137. https://doi.org/10.21744/irjmis.v7n1.830) 
3.4 The role of the audit committee in moderating the effects of institutional ownership on financial distress

The result of the analysis shows that the audit committee does not moderate the effect of institutional ownership on financial distress. Therefore, hypothesis $4\left(\mathrm{H}_{4}\right)$ which states the audit committee reinforces the negative effect of institutional ownership on financial distress is rejected. The audit committee, in general, has a direct working relationship with internal auditors, external auditors, and management (Komite Nasional Kebijakan Governance, 2002). The audit committee does not have direct access to provide confidence to institutional investors regarding the financial statements presented by management. In addition, the analytical skills possessed by institutional investors will also make institutional investors not immediately feel confident about the results of supervision conducted by the company's audit committee, because institutional investors trust the results of their own analysis.

\section{Conclusion}

Based on the results of the analysis it can be concluded that (1) managerial ownership has no effect on financial distress, (2) institutional ownership has a negative effect on financial distress, (3) the audit committee does not moderate the relationship of managerial ownership on financial distress, and (4) the audit committee does not moderate the relationship of institutional ownership on financial distress.

Based on the results of the analysis there are several suggestions that can be submitted for further researchers. First, this study only uses manufacturing companies as the scope of research. This is because the Altman Z-Score model has various types of variants, whose use is categorized based on the type of company studied. Therefore, if further research wants to generalize to all companies listed on the IDX, it is recommended to use other measurement methods such as Earning Per Share (EPS). Second, the analysis shows that the three corporate governance variables used and their interactions only affect financial distress by 3.8 percent. So that further research is recommended to use corporate governance mechanisms from the other side, such as the proportion of independent commissioners and management compensation. Third, the results of the analysis of the coefficient of determination show that 96.2 percent of the variance of financial distress is influenced by other factors outside the study. The high number of other factors outside of research that affect financial distress indicates the possibility of financial distress is also influenced by external factors. Therefore, further research is recommended to also examine the company's external factors, such as interest rates.

\section{Conflict of interest statement}

The authors declared that they have no competing interests.

\section{Statement of authorship}

The authors have a responsibility for the conception and design of the study. The authors have approved the final article.

\section{Acknowledgments}

The authors would like to thank the Editor of IRJMIS for their valuable time, support, and advice in completing the current study. 


\section{References}

Affiah, A., \& Muslih, M. (2018). Pengaruh leverage, profitabilitas, dan good corporate governance terhadap financial distress (Studi Kasus pada Perusahaan Pertambangan yang Terdaftar di Bursa Efek Indonesia Tahun 20122016). Ekspansi: Jurnal Ekonomi, Keuangan, Perbankan dan Akuntansi, 10(2), 241-256. https://doi.org/10.35313/ekspansi.v10i2.1213

Agustini, N. W., \& Wirawati, N. G. P. (2019). Pengaruh Rasio Keuangan Pada Financial distress Perusahaan Ritel Yang Terdaftar di Bursa Efek Indonesia (BEI). E-Jurnal Akuntansi, 251-280. https://doi.org/10.24843/EJA.2019.v26.i01.p10

Altman, E. I. (2013). Predicting financial distress of companies: revisiting the Z-score and ZETA® models. In Handbook of research methods and applications in empirical finance. Edward Elgar Publishing. https://doi.org/10.4337/9780857936080.00027

Anton, F. X. (2016). Menuju Teori Stewardship Manajemen. Majalah Ilmiah Informatika, 1(2).

Baklouti, N., Gautier, F., \& Affes, H. (2016). Corporate governance and financial distress of European commercial banks. Journal of Business Studies Quarterly, 7(3), 75.

Bodroastuti, T. (2009). Pengaruh Struktur Corporate Governance terhadap Financial Distress. Jurnal Aset, 11(2), 170182.

Carolina, V., Marpaung, E. I., \& Pratama, D. (2017). Analisis Rasio Keuangan untuk Memprediksi Kondisi Financial Distress (Studi Empiris pada Perusahaan Manufaktur yang Terdaftar di Bursa Efek Indonesia Periode 20142015). Jurnal Akuntansi Maranatha, 9(2). https://doi.org/10.28932/jam.v9i2.481

Chrissentia, T., \& Syarief, J. (2018). Analisis pengaruh rasio profitabilitas, leverage, likuiditas, firm age, dan kepemilikan institusional terhadap financial distress. SIMAK, 16(01), 45-62.

Cinantya, I. G. A. A. P., \& Merkusiwati, N. K. L. A. (2015). Pengaruh Corporate Governance, Financial Indicators, Dan Ukuran Perusahaan Pada Financial Distress. E-Jurnal Akuntansi, 897-915.

Dewi, N. P. R. A., \& Ramantha, I. W. (2019). Effect of conflict and unclear role on auditor performance with emotional quotient as moderating variable. International Journal of Social Sciences and Humanities, 3(3), 50-59. https://doi.org/10.29332/ijssh.v3n3.350

Eisenhardt, K. M. (1989). Building theories from case study research. Academy of management review, 14(4), 532550. https://doi.org/10.5465/amr.1989.4308385

Fadhilah, F. N., \& SYAFRUDDIN, M. (2013). Analisis Pengaruh Karakteristik Corporate Governance Terhadap Kemungkinan Financial Distress (Doctoral dissertation, Fakultas Ekonomika dan Bisnis).

Fan, J. P., \& Wong, T. J. (2002). Corporate ownership structure and the informativeness of accounting earnings in East Asia. Journal of accounting and economics, 33(3), 401-425. https://doi.org/10.1016/S0165-4101(02)00047-2

Fathonah, A. N. (2017). Pengaruh Penerapan Good Corporate Governance Terhadap Financial Distress. Jurnal Ilmiah Akuntansi, 1(2). http://dx.doi.org/10.23887/jia.v1i2.9989

Filsaraei, M., \& Moghaddam, R. J. (2016). The Impact of Corporate Governance Characteristics on the of Financial Distress. International Finance and Banking, 3(2), 162-176. https://doi.org/10.5296/ifb.v3i2.10370

Hanafi, J., \& Breliastiti, R. (2016). Peran Mekanisme Good Corporate Governance dalam Mencegah Perusahaan Mengalami Financial Distress. Jurnal Online Insan Akuntan, 1(1), 195-220.

Harahap, L. W. (2017). Pengaruh Mekanisme Corporate Governance Dan Firm Size Terhadap Kondisi Financial Distress pada Perusahaan Property And Real Estate Yang Terdaftar di Bei Tahun 2010-2014. JRAB: Jurnal Riset Akuntansi \& Bisnis, 17(2). https://doi.org/10.30596/jrab.v17i2.1721

Harmawan, D. (2013). Pengaruh Karakteristik Komite Audit, Ukuran Dewan, dan Struktur Kepemilikan terhadap Financial Distress (Studi Empiris pada Perusahaan yang Terdaftar di Bursa Efek Indonesia Tahun 2009-2011).

Jensen, M. C., \& Meckling, W. H. (1976). Theory of the firm: Managerial behavior, agency costs and ownership structure. Journal of financial economics, 3(4), 305-360. https://doi.org/10.1016/0304-405X(76)90026-X

Kalimah, S. (2017). Pengaruh Profitabilitas, Likuiditas dan Leverage Dalam Memprediksi Financial Distress (Studi Empiris Pada Perusahaan Manufaktur yang Terdaftar di BEI Periode 2009-2013). JURNAL AKUNTANSI DAN EKONOMI, 2(1), 43-66. https://doi.org/10.29407/jae.v2i1.605

Khaliq, A., Altarturi, B. H. M., Thaker, H. M. T., Harun, M. Y., \& Nahar, N. (2014). Identifying Financial distress firms: a case study of Malaysia's government linked companies (GLC). International Journal of Economics, Finance and Management, 3(3).

Komite Nasional Kebijakan Governance. (2002). Pedoman Pembentukan Komite Audit yang Efektif.

La Porta, R., Lopez-de-Silanes, F., \& Shleifer, A. (1999). Corporate ownership around the world. The journal of finance, 54(2), 471-517. https://doi.org/10.1111/0022-1082.00115

Widhiadnyana, I. K., \& Wirama, D. G. (2020). The effect of ownership structure on financial distress with audit committee as moderating variable. International Research Journal of Management, IT and Social Sciences, 7(1), 128-137. https://doi.org/10.21744/irjmis.v7n1.830) 
Luqman, R., Ul Hassan, M., Tabasum, S., Khakwani, M. S., \& Irshad, S. (2018). Probability of financial distress and proposed adoption of corporate governance structures: Evidence from Pakistan. Cogent Business \& Management, 5(1), 1492869.

Masdupi, E., Tasman, A., \& Davista, A. (2018, July). The Influence of Liquidity, Leverage and Profitability on Financial Distress of Listed Manufacturing Companies in Indonesia. In First Padang International Conference On Economics Education, Economics, Business and Management, Accounting and Entrepreneurship (PICEEBA 2018). Atlantis Press. https://dx.doi.org/10.2991/piceeba-18.2018.51

Moradi, N. S., Aldin, M. M., Heyrani, F., \& Iranmahd, M. (2012). The effect of corporate governance, corporate financing decision and ownership structure on firm performance: A panel data approach from Tehran stock exchange. International Journal of Economics and Finance, 4(6), 86-93. http://dx.doi.org/10.5539/ijef.v4n6p86

Ong'era, J., Muturi, W., Oluoch, O., \& Karanja, J. (2017). Liquidity as a Financial Antecedent to Financial Distress in Listed Companies at Nairobi Securities Exchange. Journal of Emerging Issues in Economics, Finance and Banking (JEIEFB), 6(1), 2121-2137.

Platt, H. D., \& Platt, M. B. (2002). Predicting corporate financial distress: reflections on choice-based sample bias. Journal of economics and finance, 26(2), 184-199. https://doi.org/10.1007/BF02755985

Pramudena, S. M. (2017). The Impact of Good Corporate Governance on Financial Distress in the Consumer Goods Sector. J. Fin. Bank. Review, 2(4), 46-55.

Putri, N. W. K. A., \& Merkusiwati, N. K. L. A. (2014). Pengaruh mekanisme corporate governance, likuiditas, leverage, dan ukuran perusahaan pada financial distress. E-Jurnal Akuntansi, 93-106.

Putri, Y. K. W., \& Sujana, I. K. (2018). The influence of bid-ask spread and leverage on earnings management with good corporate governance as moderating variable. International Research Journal of Management, IT and Social Sciences, 5(3), 8-21.

Raharjo, E. (2007). Teori Agensi dan Teori Stewarship dalam Perspektif Akuntansi. Fokus Ekonomi: Jurnal Ilmiah Ekonomi, 2(1). https://doi.org/10.34152/fe.2.1.\%25p

Rahmawati, T. (2016). Pengaruh kapasitas operasi, pertumbuhan penjualan, komisaris independen, dan kepemilikan publik terhadap financial distress. Jurnal Ilmu Manajemen dan Akuntansi Terapan (JIMAT), 7(2), 135-145.

Rahmawati, T., \& Hendriyana, Y. (2018). Corporate Governance to Prevent Financial Distress Evidence from Corporate Governance Perceptions Index of Indonesian Companies. Indonesian Journal Of Business And Economics, 1(1). https://doi.org/10.25134/ijbe.v1i1.1360

Ratna, I., \& Marwati, M. (2018). Analisis faktor-faktor yang mempengaruhi kondisi financial distress pada perusahaan yang delisting dari jakarta islamic index tahun 2012-2016. Jurnal Tabarru': Islamic Banking and Finance, 1(1), 51-62. https://doi.org/10.25299/jtb.2018.vol1(1).2044

Saleh, N. M., Rahman, M. R. C. A., \& Hassan, M. S. (2009). Ownership Structure and Intellectual Capital Performance in Malaysia. Asian Academy of Management Journal of Accounting and Finance, 5(1), 1-29.

Sanjaya, I. P. S. (2010). Efek entrenchment dan alignment pada manajemen laba. SNA XIII.

Sari, N. L. K. M., \& Putri, I. M. A. D. (2016). Kemampuan Profitabilitas Memoderasi Pengaruh Likuiditas Dan Leverage Terhadap Financial Distress. Jurnal Riset Akuntansi (JUARA), 6(1).

Septiani, N. M. I., \& Dana, I. M. (2019). Pengaruh likuiditas, leverage, dan kepemilikan institusional terhadap financial distress pada perusahaan property dan real estate. E-Jurnal Manajemen, 8(5), 3110-3137. https://doi.org/10.24843/EJMUNUD.2019.v08.i05.p19

Susanti, S. I. A. (2011). Pengaruh Kualitas Corporate Governance, Kualitas Audit, dan Earnings Management terhadap Kinerja Perusahaan. Jurnal Ekonomi Dan Bisnis, 5(2), 145-161.

Sutojo, S., \& Aldridge, E. J. (2005). Good Corporate Governance Tata Kelola Perusahaan yang Sehat. Jakarta: PT Danar Mulia Pustaka, hal, 237.

Udin, S., Khan, M. A., \& Javid, A. Y. (2017). The effects of ownership structure on likelihood of financial distress: an empirical evidence. Corporate Governance: The international journal of business in society, 17(4), 589-612. https://doi.org/10.1108/CG-03-2016-0067

Ufo, A. (2015). Impact of financial distress on the leverage of selected manufacturing firms of Ethiopia. Industrial Engineering Letters, 5(10), 6-11.

Waqas, H., \& Md-Rus, R. (2018). Predicting financial distress: Importance of accounting and firm-specific market variables for Pakistan's listed firms. Cogent Economics \& Finance, 6(1), 1545739. https://doi.org/10.1080/23322039.2018.1545739

Yayanti, V., \& Yanti, Y. (2016). Analisis Pengaruh Likuiditas, Efisiensi Operasi, Dan Corporate Governance Terhadap Financial Distress Pada Perusahaan Manufaktur Yang Terdaftar Di Bursa Efek Indonesia Pada Periode 2012- 
2014. Jurnal Ekonomi., 20(1).

Yudha, A., \& Fuad, F. (2014). Analisis pengaruh penerapan mekanisme corporate governance terhadap kemungkinan perusahaan mengalami kondisi financial distress (Studi Empiris Perusahaan Manufaktur yang Terdaftar di Bursa Efek Indonesia Tahun 2010-2012). Diponegoro Journal of Accounting, 430-441.

Yudiana, I. G. Y., \& Yadnyana, I. K. (2016). Pengaruh Kepemilikan Manajerial, Leverage, Investment Opportunity Set Dan Profitabilitas Pada Kebijakan Dividen Perusahaan Manufaktur. E-Jurnal Akuntansi, 111-141.

Zahra, K., Khan, M. J., \& Warraich, M. A. (2018). CEO Characteristics and the Probability of Financial Distress: Evidence from Pakistan. NUML International Journal of Business \& Management, 13(2), 117-129.

Widhiadnyana, I. K., \& Wirama, D. G. (2020). The effect of ownership structure on financial distress with audit committee as moderating variable. International Research Journal of Management, IT and Social Sciences, 7(1), 128-137. https://doi.org/10.21744/irjmis.v7n1.830) 